\title{
The Influence of Institutional Factors on Sustainable Renewable Energy Policy Development: New Evidence from the Thai Experience
}

\author{
Pasakorn Sakolsatayatorn (Corresponding author) \\ Graduate School of Public Administration, National Institute of Development \\ Administration \\ 118, Seri Thai, 10240, Bangkapi, Bangkok, Thailand \\ E-mail: jaypasakorn@gmail.com
}

Received: December 12, 2018

Accepted: January 25, 2019 Published: January 30, 2019

doi:10.5296/ijgs.v3i1.14052

URL: https://doi.org/10.5296/ijgs.v3i1.14052

\begin{abstract}
Renewable energy has become the buzzword in the 21 st century especially during the United Nations declarations of the Submit 21 in which world leaders renewed their efforts in achieving the seventeen sustainable development goals. One of the challenges of the developing world is achieving a reliable energy supply for industrialization and energy security. Thailand is one of the countries with the highest energy consumption within the ASEAN region and hence, several policies have been implemented to deploy a clean source of energy for both domestic and manufacturing purposes. However, there are many institutional factors that seem to impede this drive for a greener energy supply in the country. This study sought to investigate the institutional factors that support sustainable renewable energy policy development in the Thai context. The study selected 400 respondents from renewable energy producing companies in Bangkok and Ayutthaya using a survey instrument. The results were analyze using SPSS version 22.0 with multiple regression technique. The results showed that institutional variables such as stakeholder involvement, government R\&D framework, regulatory procedures, and government subsidies had an influence on sustainable renewable policy development. The study recommends that future government policies should engage key stakeholders in the policy dialogue and implementation process. Keywords: Renewable energy, Sustainable policy, Stakeholder involvement, Thai context, Government R\&D
\end{abstract}




\section{Introduction}

Energy sustainability became a buzzword by the end of the Millennium Development Goals (MDGs) deadline since 2012 (Nilsson, Lucas, \& Yoshida, 2013). One of the central problems that many nations face today is how to increase their energy sources to meet the growing demands of both domestic and industrial use (Azuela, G. E. and Barroso, 2012; Beck \& Martinot, 2004). While many countries have started making giant strives especially Germany, China and Japan in renewable energy (RE) sources in terms of policy (Cong \& Shen, 2014; Urban, 2009), other countries have largely lagged behind (International Renewable Energy Agency, 2012). Globally, there is a growing need for policies to promote the deployment of RE power supply (Emodi \& Ebele, 2016; Lüthi, 2011; Sawin, Seyboth, \& Sverrisson, 2016).

For a number of reasons, in 2010, more than 100 countries had enacted some type of policy target and policies to increase renewbale energy (RE) (Sawin et al., 2016). First, RE can help solve climate change and increase the energy demand. Second, REs may bring about new business opportunities to the value chain by ensuring transformative, and productive industrial development (Buckley \& Nicholas, 2017; International Renewable Energy Agency, 2012), while at the same time, RE can lead to social impacts or benefits like job creation, cheaper energy sources to reduce electricity tariffs.

Although RE deployment has prospects in developing countries, the ability of these countries to develop more attractive policy measures to attract more investment and build new industries, technologies and job creation (Al-Sarihi, Contestabile, \& Cherni, 2015; IRENA, 2017) are mostly lacking. Among the most successful countries are China and Germany who through effective policy development has succeeded in RE deployment and production (Emodi \& Ebele, 2016; International Renewable Energy Agency, 2012). At the global level, the installed capacity of RE is 18 per cent and with the rate at which global warming and climate change is approaching, the reliance on RE sources that reduces the use of fossil fuels and release of CFC gases is necessary to manage environmental sustainability (Beck \& Martinot, 2004; Wiser \& Pickle, 1997).

Accordingly, scholars have argued that full deployment of RE sources depend to a very large extent, the on ability of a country to develop effective policy measures and minimize the barriers that militate against private sector involvement (Achawangkul, 2017; Al-Sarihi et al., 2015; Beck \& Martinot, 2004; Buckley \& Nicholas, 2017; Emodi \& Ebele, 2016; Menanteau, Finon, \& Lamy, 2003). Similarly, studies such as (Beck \& Martinot, 2004; Emodi \& Ebele, 2016; International Renewable Energy Agency, 2012) have focused on energy policies analysis globally by looking at the effect of privatization and public-private partnership arrangements (International Energy Agency (IEA), 2011; Nsasira, Basheka, \& Oluka, 2013; Pongsiri, 2004). While admitting that these studies have provided explanations on RE policies risk assessment analysis (Beck \& Martinot, 2004; Menanteau et al., 2003), economic analysis (Al-Sarihi et al., 2015; Timmons, Harris, \& Roach, 2009), environmental analysis (Al-Sarihi et al., 2015; Denholm, 2004; Konkel, 2013), little is known on how institutional factors influence policy development in the RE sector in developing countries. However, few studies have focused on the sustainability of RE policies taking into account institutional 
factors that drive policy development (Ali., 2012; Emodi \& Ebele, 2016; Konkel, 2013; Musango \& Brent, 2010; Nilsson et al., 2013; Okundamiya, Emagbetere, \& Ogujor, 2014; Urban, 2009; Vilanova, Magalh\&atilde; es Filho, \& Balestieri, 2015).

The fundamental quest and the need to develop sustainable RE policy in Thailand by analysing the institutional drivers form the major focus of this study. As a result, four institutional variables were of importance: stakeholder involvement, regulatory/administrative procedures, government R\&D framework, and government subsidies, which sought to test the effect of these variables on sustainable RE policy development in the Thai context. These factors are important because, they form part of the core of obtaining operating permits for RE production as well as defining the policy framework on RE. Specifically, the study main research question is as follows:

How do institutional factors impact on sustainable renewable energy policy development?

\section{Literature Review}

Many socio-economic benefits have been linked to the deployment of RE. These include job creation, the creation of new federal and tax revenues and more significantly, the revitalisation of struggling communities. In order to achieve all these associated benefits, strong institutional support in the form of government policies and incentives that favour the deployment of RE is required (Sheikh, Kocaoglu, \& Lutzenhiser, 2016). Thus, the deployment of RE is influenced greatly by the institutional and its accompanying administrative elements of the country. These institutional policies are more of an institutional decision than it is of an investment decision. Consequently, the deployment and acceptability of any form of RE will require the support of governmental institutions (IEA, 2011).

Several institutional factors have been identified in the literature to have some form of impact on the decision to deploy RE. These include lengthy regulatory approvals and permit procedures, policy instability, lack of subsidies, lack of institutional commitment, inadequate legal and regulatory framework and land or water lease problems (Byrnes, Brown, Foster, \& Wagner, 2013; Luthra, Kumar, Garg, \& Haleem, 2015; Nasirov, Silva, \& Agostini, 2015). Sheikh et al (2016) have aggregated these institutional factors to include: political stability, regulation or deregulation of the market, policy and government research and development programmes.

\subsection{Sustainable Policy Development}

Chalvatzis and Hooper (2009) highlight the importance of a favorable policy environment for the development of RE. Comparing Germany and Greece, they showed how both countries use FITs as a policy to promote RE usage. They argued that Germany has one highest RE penetration in the world due to a high level of institutional support and many supporting policies resulting in long-term certainty required by investors. It is important to point out that FITs were introduced in the year 2000 in Germany.

In 1994, Greece also introduced FITs with a combined investment subsidy of between 30 per 
cent and 50 per cent meanwhile capacity building in RE electricity has remained poor. These differences in achieved results have been attributed to many factors including variability of potential, interconnection availability and implementation processes which all boil down to the political support given to RE technology (Chalvatzis \& Hooper, 2009).

Emodi and Ebele (2016) also cited the poor implementation of RE policies as one of the challenges of low deployment in Nigeria. They also mentioned the lack of government support in the form of a pricing mechanism, funds and research and development as other policy challenges in Nigeria. Still, on the general policy environment, the lack of commitment on the part of policymakers has also hindered the growth of the RE sector greatly. The potential of RE cannot be exploited without clear political vision with efficient scientific and technological support (Srivastava \& Sharma, 2013). Luthra et al. (2015) assert that the issue of political commitment in India has been a matter of politics as well as a strategic challenge.

In addition, policy instability also poses significant challenges to the development of renewable energy sources. Frequent policy changes and abrupt discontinuation of policies undermine the growth of the RE sector (Lucas, Fifita, Talab, Marschel, \& Cabeza, 2017; Meyer, 2007; Wiser \& Pickle, 1997).

Byrnes et al. (2013) asserted that incompatible priority setting by political actors tends to weaken the effectiveness of the existing policy plans. They reported that the new government in Queensland in 2012, cancelled most state RE funding with only solar feed-in-tariffs left untouched. Such development only erodes the gains made by previous policies.

\subsubsection{Regulatory and Administrative Procedures}

The regulatory policy framework can pose a big threat to renewable energy advancement depending on how it is framed (EWEA, 2010 cited in Luthi \& Prassler, 2011; Luthi \& Prassler, 2011). Sheikh et al (2016) identified RE policy sub-criteria as follows: energy security, support for renewable energy in the form of "Feed-in-Tariffs and Renewable Portfolio Standards (RPSs)", financing options with "government backing, local sourcing", five years or ten years RE plans. Also, the integration of existing power plants among other factors as the policy issues that can spur or stifle the development of RE technology. Generally, a major challenge to the deployment of renewable technology has to do with the absence of appropriate RE policies and the environment.

Noim, Uddin and Taplin (2009) asserted for example that the low levels of deployment in Bangladesh are because of lack of appropriate policy setting in Bangladesh. In an analysis in Australia, "administrative hurdles, delays in project approvals" and high levels of multi-tiered regulations were identified as policy barriers to deployment (Martin \& Rice, 2015; Noim Uddin \& Taplin, 2009).

In Chile, it is reported that high levels of bureaucracy in governmental bodies make the entire process excessively long and complicated. Several authorities and different administrative levels within each authority are normally involved. Consequently, delays may exceed 700 days on average (Byrnes et al., 2013). Closely related to the delays and long administrative 
processes is the acquisition of environmental approval for RE companies. The Environmental Impact Evaluation System (EIES) is the most critical permit for RE developers in Chile. However, it is surrounded by so much uncertainty about the required time to obtain. It is reported that the time span may vary between 90 and 210 days, depending on the nature of the project (Byrnes et al., 2013).

Similarly, Nasirov et al. (2015) identified some of the regulatory barriers to RE deployment to include: lack of stable energy policy, lack of confidence in RE technology, inadequately equipped government policies. In India for example, there are no comprehensive policy statements for RE and the lack of grid access regulations.

\subsubsection{Government Subsidies}

Policies are said to be issued as and when necessary to facilitate the growth of specific RE technology (Luthra et al., 2015). The state of RE legal and regulatory framework in a country can also work to enhance or undermine the deployment of RE. Sheikh et al. (2016) have identified subsidies, energy price controls, FITs, Tax exemptions as some of the regulatory measures that can impact either negatively or positively on RE technology deployment.

Some studies have categorized the provision of subsidies as an economic factor. However, it is more of an institutional factor than an economic factor. When analyzed critically, the decision to provide subsidies largely resides with policymakers. Some countries subsidize RE through production payments or rebates. Rebates are refunds of a specific share of the cost of a technology or share of total installation cost (Sawin et al., 2016). Also, access to financial and tax incentives like a subsidy, low-interest loans, and tax exemption among others may improve the viability and affordability of RE projects (Thanh Nguyen, Ha-Duong, Tran, Shrestha, \& Nadaud, 2010).

In Denmark support to RE technology is given in the form of environmental tax. Since 1992, there have been in place a $\mathrm{CO} 2$ tax, and part of the revenue generated is used to pay generators of RE (Fouquet \& Johansson, 2005). Sweden has also been cited to have use environmental tax to promote the growth of RE deployment (Joelsson, 2011). Similarly, Germany has one of the highest penetrations of RE technologies in the EU, partly due to an array of fiscal policies in support of RE deployment. The main RE supporting policy is the FIT, which was implemented in 2000 and revised in 2004 (Chalvatzis \& Hooper, 2009).

\subsubsection{Government Research Development Framework}

The government has a major role to play in accelerating the development and deployment of renewable technology through the funding of research and the provision of supportive research and development (Sheikh et al., 2016; Emodi \& Ebele, 2016).

Most national laboratories in the USA had some form of RE R\&D in place for decades, particularly, the National Renewable Energy Laboratory (NREL) (Sheikh et al., 2016: p. 106). However, it is important to point out that funding from government may not be enough to increase $\mathrm{R} \& \mathrm{D}$ activities, therefore, private sector investment is vital for the realisation of technological innovation and diffusion in the RE sector (Emodi \& Ebele, 2016). 


\subsubsection{Stakeholder Involvement}

The issue of land acquisition is also a major policy concern which continues to be a major issue when it comes to RE deployment. Indeed, the issues of land have been identified as the major "source of failure in the development of renewable" energy in Latin America. The lack of "frameworks and adequate consultation" with directly impacted communities are the common challenges (Nasirov et al., 2015). As a result of these challenges, large hydro projects in Argentina and Chile were suspended in 2011 and 2014 respectively (Varas, Tironi, Rudnick, \& Rodriguez, 2013).

Closely related to this point is the problem of short-term policy horizons which makes long-term planning difficult and reduces confidence by market participants to plan and respond more efficiently (Vine et al., 2003).

\subsubsection{A Brief Background of Thailand's Renewable Energy Policy}

Electricity is the main form of energy consumption in developing countries. In Thailand, 67\% $(119,434 \mathrm{GWh})$ of primary energy resource for electricity generation relies on natural gas. Therefore, it may not be sustainable in the future. In 2012, it was estimated that carbon dioxide (CO2) emission of 95,734 ktonne was released to the environment due to fossil-based electricity generation (Energy Planning and Policy Office, Ministry of Energy, Thailand, 2013). To reduce the amount of $\mathrm{CO} 2$ emission and to prevent instability of energy resources, the Alternative Energy Development Plan (AEDP) 2012-2021 launched the plan to reduce the fossil fuel consumption and to increase energy security in Thailand.

However, costs of electricity generation from renewable energy are higher than conventional power generation resulting in less economic interest to investors. Therefore, the government has launched a policy to motivate private sector to invest in renewable electricity generation since 2007, known as "Adder". Adder costs are charged on top of the national electricity generation cost resulting in higher production cost. However, in 2014, the Thai Government replaced the 'adder rate' with 'feed-in-tariff' (FIT) and this new policy has been in operations with new strategies to support RE deployment in the country.

Compared with other Southeast Asian countries, Thailand has the highest electricity demand, with plans for increased imports from neighboring Laos, Myanmar, Cambodia, and China (Ministry of Energy, 2016). Over the past 10 years, electricity demand has been growing at about $770 \mathrm{MW}$ per year or about $3.2 \%$ per year. The current installed capacity is 32,200 MW, with the majority of energy sources from natural gas (67\%) and coal (20\%) (Energy Policy and Planning Office, 2017). Non-hydro RE contributes a minor (around 5\%) but increasing the share of the total electric power generation (Department of Alternative Energy Development of Efficiency, 2012; Tongsopit \& Greacen, 2013).

Thailand's energy policy on RE has barely made gains (Tongsopit, 2016; Tongsopit \& Greacen, 2013). Despite the role that the production and use of RE sources provides, policy measures that support the private sector are inadequate (Jue, Johnson, \& Vanamali, 2012; Keyuraphan, Thanarak, Ketjoy, \& Rakwichian, 2012). Also, insufficient grid capacity, non-transparent costly procedures for grid connection, sudden policy changes are some of the 
challenges facing the RE sector in the country (Pongsiri, 2003). The installed capacity of RE in Thailand was 10.9 percent in 2013, 11.3 percent in 2014 and it is expected that by 2021, the installed capacity will increase to 25 percent (Department of Alternative Energy Development, 2014). However, the country primary source of energy is the natural gas which constitutes about $67 \%$, an average of $119,434 \mathrm{GWh}$, hence the current energy sources will not be sustainable because of the unreliabile nature of the traditional sources of power (National Alternative Energy Development Authority, 2015). The AEDP (2015) maintains that the policy is expected to achieve a full generation capacity by 2040 . Nevertheless, Thailand is motivated to transition to RE because the country's energy import is expected to rise from 42 percent (2013) to 78 percent in 2040. The share of the natural gas imports almost doubles due to declining domestic production and the high demand for power generation.

Consequently, to limit the energy imports, the national power plan under the Alternative Energy Development Plan (AEDP 2015-2036) foresees that by 2040, biomass will have the largest share of 13 percent $(11 \mathrm{GW})$, solar-photovoltaic (PV), 9 percent $(8 \mathrm{GW})$, wind 6 percent $(5 \mathrm{GW})$ and hydropower, 5 percent $(4 \mathrm{GW})$. To be able to address the energy gap and provide a sustainable energy future, the Government of Thailand has developed a roadmap or policy guidelines for increasing the current stock of RE through the Alternative Energy Development Policy which is known as the "Feed in Tariffs" policy to replace the "Adder rates" policy (Achawangkul, 2017; Keyuraphan et al., 2012; Tongsopit, 2016; Wattana, 2014).

Although the policy is a measure to motivate the private sector to partner with government to provide electricity and power to meet the growing demands of domestic and industrial sectors, recent studies suggest that the lack of clarity of policy objectives, low technical and institutional capacity, regulatory barriers, and access to capital investments (Keyuraphan et al., 2012; Square \& Tongsopit, 2016) are the major challenges that may affect the drive towards RE sustainability in Thailand.

\section{Methods and Results}

\subsection{Methods}

This study was conducted in Thailand in two provinces, Bangkok, and Ayutthaya. The data was collected from engineers, CEOs, MDs, Senior Government Officers from key government institutions and solar energy producing companies in the two provinces between January 20018 to July 2018. The reason for choosing these categories of respondents was informed by their knowledge and the role they play in the energy mix especially renewable sources of energy. The SPSS version 22.0 was used analyze the data. The main analytic tool used in the analysis was standard multiple regression technique after checking for the assumptions of the use of regression analysis

In all 250 answered questionnaires were returned out of the 400 -survey pack distributed to respondents representing a response rate of $62.5 \%$. However, after screening and cleaning the data, only 166 questionnaires were useable giving a response rate of $66.4 \%$ out of the 250 questionnaires received. The answered questionnaires were checked for completeness and 
accuracy before the final decision to use all the questionnaires for the analysis since only two (2) out of the 166 had few missing data hence the decision to use them. The sample included 120 males $(72.3 \%)$ and 46 females $(27.7 \%)$. The minimum age is 23 and the maximum age is 60.

\subsubsection{Procedures}

The dependent variable for the study is sustainable RE policy development which was measured by two indicators: effective policy measures and policy stability. The independent variables were as follows: government subsidies, government R\&D framework, regulatory/administrative procedures, and stakeholder involvement.

\subsubsection{Measures}

The measures for the variables were adopted from previous studies. Several indicators have been used to represent sustainable RE policy, this study represents sustainable RE policy development using effective policy measures and policy stability (Byrnes et al., 2013; Chapman, 2016). Effective policy measures are measured by the quality of the processes that lead to the adoption of a policy adoption and implementation (Emodi \& Ebele, 2016). While policy stability is measured by the extent to which policy changes over time (Emodi \& Ebele, 2016). A reliability test was performed for the four variables, and the results showed that the Cronbach Alpha for the variables were above 0.70 (See Table 1 below). Except for government subsidy which was a single-item scale for which a reliability test was not used because it was a categorical scale with two options: "yes or no". For the complete measures of the variables refer to appendix 1.

Table 1. Cronbach alpha for the main scales

\begin{tabular}{llll}
\hline Variable & Number of Items & Cronbach Alpha & No. of Cases \\
\hline $\begin{array}{l}\text { Sustainable RE policy } \\
\begin{array}{l}\text { Development } \\
\text { Government R\&D }\end{array}\end{array}$ & 4 & 0.82 & 165 \\
$\begin{array}{l}\text { Regulatory/Administrative } \\
\text { procedures }\end{array}$ & 8 & 0.90 & 164 \\
Stakeholder involvement & 8 & 0.73 & 164 \\
\hline
\end{tabular}

\subsection{Results}

\subsubsection{Descriptive Statistics}

Government R\&D framework had a mean score of 6.01, a standard deviation of 2.06, with the minimum score being 0 , and the maximum score is 10 . Similarly, regulatory $\&$ administrative procedures had an average score of 5.73, the standard deviation of 1.65, a minimum score of 0 and the maximum score is 10 . Stakeholder involvement had a mean score of 5.55, the standard 


\section{Macrothink}

deviation of 1.34, with a minimum score of 2 and the maximum score is 10 . While the mean score for government subsidies is $1.69, \mathrm{SD}=0.47$. The minimum score is 1 and the maximum score is 2 . For the dependent variable: sustainable RE policy development, the minimum score is 3 and the maximum score is 12 , with a mean score of 6.77 , a standard deviation of 1.51 (See Table 2 below).

Table 2. Descriptive statistics for variables

\begin{tabular}{lllll}
\hline Variable & Mean & Standard Deviation & Minimum & Maximum \\
\hline $\begin{array}{l}\text { Sustainable RE policy } \\
\text { Development }\end{array}$ & 6.77 & 1.51 & 3 & 13 \\
Government Subsidies & 1.69 & 0.47 & 1 & 2 \\
Government R\&D & 6.01 & 2.06 & 0 & 10 \\
Regulatory/Administrative & 5.73 & 1.65 & 0 & 10 \\
procedures & & & & 10 \\
Stakeholder involvement & 5.55 & 1.34 & 0 & 10 \\
\hline
\end{tabular}

\subsubsection{Bivariant Analysis}

After a preliminary test of the various assumption of the multiple regression analysis techniques, the data was found to be devoid of multicollinearity and there was no collinearity presence in the data. A bivariant analysis was performed to observe the correlation between the independent variables: government subsidies, government R\&D, regulatory/administrative procedures \& stakeholder involvement, and the dependent variable: sustainable RE policy development. The results of the correlation showed that most of the variables had correlation values higher than 0.2 and less than 0.8 .

In Table 2 below, the results showed that there is a negative and significant correlation between sustainable RE policy development and government subsidies $(\beta=-0.23, p<0.05)$. The relationship between government $R \& D$ and sustainable $R E$ policy development is positive and statistically significant at $(\beta=0.66, \mathrm{p}<0.05)$, while regulatory/administrative procedures and the dependent variable were significant at $(\beta=0.56, p<0.05)$. Also, the correlation between stakeholder involvement and the dependent variable: sustainable $\mathrm{RE}$ policy development is strongly correlated and statistically significant at $(\beta=0.68, p<0.05)$.

Regulatory/administrative procedures provided a strong relationship with the other variables. For instance, regulatory/administrative procedures and government subsidies were statistically significant at $(\beta=-0.26, p<0.01)$, government $R \& D$ is $(\beta=0.58, p<0.05)$, stakeholder involvement is $(\beta=0.59, \mathrm{p}<0.05)$. While government subsidies and government $\mathrm{R}$ $\& D$ is negative and significant at $(\beta=-0.17, \mathrm{p}<0.01)$. 
Table 3. Correlation results for variables

\begin{tabular}{llllll}
\hline Variable & $\mathbf{1}$ & $\mathbf{2}$ & $\mathbf{3}$ & $\mathbf{4}$ & $\mathbf{5}$ \\
\hline Sustainable RE policy dev. & 1 & & & & \\
Government Subsidies & $-0.227^{* *}$ & 1 & & & \\
Government R\&D & $0.661^{* *}$ & $-0.170^{*}$ & 1 & & \\
Regulatory/Admin procedures & $0.545^{* *}$ & $-0.261^{* *}$ & $0.576^{* *}$ & 1 & \\
Stakeholder involvement & $0.679^{* *}$ & $-0.231^{* *}$ & $0.569^{* *}$ & $0.586^{* *}$ & 1 \\
\hline
\end{tabular}

Note: $* *=\mathrm{P}<0.05, *=\mathrm{P}<0.01$.

\subsubsection{Regression Results}

The results for the regression analysis indicated that the four sub-components of the institutional determinants were positive. The regression model was able to explain $53.9 \%$ of the variation in the dependent variable: sustainable $R E$ policy development $(\mathrm{r} 2=0.539)$. The results are presented in Table 4 below.

Table 4. Regression results

\begin{tabular}{llll}
\hline Variable & Beta & T-Stat & P-value \\
\hline Constant & 2.509 & 4.725 & 0.000 \\
Government Subsidies & -0.042 & -0.748 & 0.455 \\
Government R\&D & 0.274 & 3.907 & 0.112 \\
Regulatory/Admin procedures & 0.115 & 1.598 & 0.000 \\
Stakeholder involvement & 0.446 & 6.282 & 0.000 \\
Model Summary Statistics & & & \\
R & 0.734 & & \\
$\mathrm{R}^{2}$ & 0.539 & & \\
Adjusted R & & \\
S. E & 0.528 & & \\
f-stat & 1.019 & & \\
df & 46.784 & & \\
P-value & 160 & & \\
\hline
\end{tabular}

Note: Dependent Variable: Sustainable RE Policy Development, standardized beta values: Method: Enter. 


\section{Macrothink}

The table above suggests that stakeholder involvement provided more explanatory power with a $\beta=0.45$, followed by government $R \& D$ framework, which contributed $\beta=0.27$, while regulatory/administrative procedures and government subsidies provided the least in explaining the dependent variable with $\beta=0.12$ and $\beta=-0.04$ respectively. However, the regression result for government subsidies was negative suggesting an inverse relationship between the two variables. The implication is that a unit change in regulatory procedures leads to a decrease in sustainable RE policy development. While this is the case, the finding needs to be interpreted with caution since it does not mean that regulatory procedures lead to unsustainability of RE policies. However, this finding may suggest that there are fundamental challenges with the regulatory and administrative procedures in place to support investors in startup ventures in the energy sector.

In terms of significant effects, two variables: government R\&D framework and stakeholder involvement were statistically significant. Where the $\mathrm{p}$-values for the two variables were less than $(<0.000)$ indicating a highly significant effect at $99 \%$ confidence level suggesting that the effect was not due to chance. The following table is used to test the hypotheses of the study:

Table 5. Hypotheses testing for the main effects

\begin{tabular}{lllll}
\hline Model & Independent Variable & B & Prediction & Outcome \\
\hline 1 & Gov. subsidies & -0.042 & + & $-(\mathrm{ns})$ \\
& Government R\&D & $0.274 * * *$ & + & $* * *$ \\
& Regulatory/admin procedures & 0.115 & + & $(\mathrm{ns})$ \\
& Stakeholder involvement & $0.446^{* * *}$ & + & $* * *$ \\
\hline
\end{tabular}

Note: Dependent variable: Sustainable RE policy development. standardized beta vales

\section{Discussion}

The findings indicate that institutional factors either support or limited RE policy sustainability (Emodi \& Ebele, 2016). For instance, the results for government investment in $R \& D$ was highly significant (coefficient $=0.274, p<0.001$ ) indicating a strong support for $R E$ policy development. This finding is consistent with the literature which indicate that investments in research and development activities in the renewable sector has the potential to discover more technologies to improve and increase the share of the renewables to the grid capacity (Musango \& Brent, 2010; Nilsson, Lucas, \& Yoshida, 2013; Okundamiya, Emagbetere, \& Ogujor, 2014; Urban, 2009; Vilanova, Magalhatilde;es, Filho, \& Balestieri, 2015).

Also, one significant finding which confirms previous studies indicates that stakeholder involvement is an important variable that supports the sustainability drive of renewable policies globally (IEA, 2012). The results from this study provide a strong foundation and 
empirical evidence that stakeholder consultation and participation is needed in achieving policy goals. The variable contributed the most (coefficient $=0.446, \mathrm{P}<0.001$ ) to explain the total variance in the dependent variable.

Further, regulatory /administrative procedures and government subsidies did not have a significant effect on the dependent variable. However, regulatory/administrative procedures had a positive relationship but insignificant effect on sustainable RE policy development. This finding deviates from previous studies such as (EWEA, 2010 cited in Luthi \& Prassler, 2011; Luthi \& Prassler, 2011) that administrative bottlenecks had a significant impact on RE policy implementation. While this finding may be due to the sample population and the Thai context, its interpretation should be treated with caution because not having statistical significance may not rule out the importance of administrative and regulatory procedures in policy sustainability and effectiveness (Achawangkul, 2017; Al-Sarihi et al., 2015; Beck \& Martinot, 2004; Buckley \& Nicholas, 2017; Emodi \& Ebele, 2016; Menanteau, Finon, \& Lamy, 2003). However, what this finding implies is that regulatory and administrative procedures do have some relationship with the policy process and if neglected may affect the desired outcomes on the policy goals. This is supported with evidence from previous studies that regulatory and undue delay of the administrative procedures often leads to bureaucratic red tape and corrupt practices by civil servants (Byrnes et al., 2013; Luthra et al., 2015; Nasirov et al., 2015; Sheikh et al., 2016.

Another interesting finding in this study is government subsidy to investors which is said to be effective in attracting more investors in the RE sector in different countries like China and Germany (Fouquet \& Johansson, 2005; Tongsopit \& Greacen, 2013). However, the finding in this study does not support this evidence because the results suggest a negative relationship and insignificant effect on the dependent variable. While this finding may hold true for the sample population, other factors that exist in different settings like government tax incentives, tax holidays, and financial credit to investors, are substantially missing in the Thai model. Yet the Ministry of Energy (2015) annual reports suggest that government provides financial incentives through stable prices under the adder rate policy which gave investors an added fee in addition to the electricity base fee for 7 and 10 years for the different RE types. At the same time, the current policy on feed-in-tariff indicates that government is providing incentives through a fixed pricing policy which lengthens the payback period between 20 and 25 years for biomass, biogas, wind, MSW and other RE types and solar energy respectively (Tongsopit \& Greacen, 2013).

\section{Conclusion and Implications for Future Research}

The findings suggest that stakeholder involvement is viewed as a significant antecedent of sustainable RE policy development and effective in achieving the stated goals and objectives of Thailand's Alternative Energy Development Plan. This study confirms that stakeholder consultation and dialogue is a key determinant to successful outcomes on RE policy goals. Therefore, government agencies responsible for policy development in the RE sector should involve power producers and communities in the formulation and implementation of policies to achieve the government's target of $40 \%$ RE consumption by 2036 . 


\section{Macrothink

The study indicates that there are little government investments in $R \& D$, yet the contribution of R\&D is significant in fostering sustainability of government policies on RE in the country. While the few R\&D activities are being pursued, they are not well targeted to ensure that the learning and development centres enhance the technology used in the RE sector like Germany and other global contenders. Therefore, efforts in increasing and targeting training and development activities to ensure that the country builds its own RE technology, may in long-run reduce the initial cost for installing $\mathrm{RE}$ technologies.

Regulations and administrative procedures need to be strengthened and made effective in serving customers, especially investors. The findings imply that regulations and administrative procedures are characterised by bureaucratic bottlenecks and red tape. Also, the queuing time is undefined and sometimes people take advantage of the situation by jumping the queue. For example, the findings indicated that local governments and local partners deliberately delay the issuance of RE permits with the hope of requesting high-profit sharing from investors. Additionally, corrupt practices are a phenomenon in the issuance of operating permits and undue delays leading to payments of cash to some middlemen or corrupt officials.

The findings suggest that there are little government direct subsidies through financial engineering to investors. However, incentives are provided by the government in the form of the pricing mechanism, especially under adder rate and the feed-in-tariff to attract investors into the production of RE. It is important to note that there are no direct tax incentives for producers under the current policy except the fixed number of years between 20-25 years for the payback period depending on the type of RE. However, the government's target of $40 \%$ RE consumption by 2036 is not realistic without incentivizing producers. Most of the investors who produce RE power are likely to fold up because low prices are being offered for their products. For instance, solar is between 4.50-3.0 baht while biomass, biogas and others attract about 2.50 baht under the FiT policy unlike the adder rate which paid 8.0 baht for solar and 2.50 baht for waste and others exclusive of the electricity base price.

This study has a few limitations due to the small sample size (166) used in the analysis. Subsequently, the findings need to be treated with caution and further studies should focus on the relationship between trust and administrative procedures using longitudinal techniques to understand the transactional behaviour of both public officers and potential investors. Similarly, future studies should explain how stakeholder involvement contributes to sustainable RE policy development.

\section{Acknowledgement}

The research is part of my $\mathrm{PhD}$ dissertation towards an award of a doctor of philosophy degree, Development Administration from National Institute of Development Administration, NIDA.

\section{References}

Ali., S. S. (2012). Analysis of solar energy production, utilisation and management for facilitating sustainable development in and around the deserts of Pakistan. The University of 
Manchester.

Achawangkul, Y. (2017). Thailand's Alternative Energy Development Plan. In National Dialogue on the Urban Nexus in Thailand (pp. 1-11). Bangkok, Thailand.

Al-Sarihi, A., Contestabile, M., \& Cherni, J. A. (2015). Renewable Energy Policy Evaluation Using A System Dynamics Approach: The Case of Oman. In The 33rd International Conference of the System Dynamics Society, Cambridge, USA (pp. 50-60). Cambridge, USA.

Alternative Energy and Efficiency Information Center, D. of A. E. D. \& M. of E. (2014). Statistic: power usage 2012-2014. Bangkok. Retrieved from: http://www.dede.go.th/dede/index.php?option=com_content\&view=article\&id=1841\&Itemid $=318 \&$ lang $=$ en

Azuela, G. E., \& Barroso, L. A. (2012). Design and Performance of Policy Instruments to Promote the Development of Renewable Energy (Energy and Mining Sector Board Discussion Paper No. No.22). Washington D.C.

Beck, F., \& Martinot, E. (2004). Renewable Energy Policies and Barriers. Encyclopedia of Energy. https://doi.org/10.1016/B0-12-176480-X/00488-5

Buckley, T., \& Nicholas, S. (2017). Japan: Greater Energy Security Through Renewables Electricity Transformation in a Post-Nuclear Economy, 1-42. Institute for Energy Economics and Financial Analysis. Retrieved from http://ieefa.org/ieefa-report-renewables-path-japan ese-energy-security-post-nuclear-era/_

Byrnes, L., Brown, C., Foster, J., \& Wagner, L. D. (2013). Australian renewable energy policy: Barriers and challenges. Renewable Energy, 60, 711-721. https://doi.org/10.1016/j.re nene.2013.06.024

Chalvatzis, K. J., \& Hooper, E. (2009). Energy security vs. climate change: Theoretical framework development and experience in selected EU electricity markets. Renewable and Sustainable Energy Reviews, 13(9), 2703-2709. https://doi.org/10.1016/j.rser.2009.07.013

Chapman, A. J. (2016). A Framework for Energy Policy Evaluation and Improvement Incorporating Quantified Social Equity. Kyoto University.

Cong, R. G., \& Shen, S. (2014). How to develop renewable power in China? A cost-effective perspective. The Scientific World Journal. https://doi.org/10.1155/2014/946932

Denholm, P. L. (2004). Environmental and policy analysis of renewable energy enabling technologies. Fusion Technology Institute, University of Wisconsin. Retrieved from http://fti.neep.wisc.edu

Department of Alternative Energy Development of Efficiency. (2012). Alternative Energy Development Plan (2012-2021), 7(1), 1-10.

Emodi, N. V., \& Ebele, N. E. (2016). Policies Enhancing Renewable Energy Development and Implications for Nigeria. Sustainable Energy, 4(1), 7-16. 


\section{Macrothink}

International Journal of Global Sustainability

ISSN 1937-7924

2019, Vol. 3, No. 1

Fouquet, D., \& Johansson, T. (2005). Energy and environmental tax models from Europe and their link to other instruments for sustainability: policy evaluation and dynamics of regional integration. In Eighth Senior Policy Advisory Committee Meeting. Beijing, China.

International Energy Agency (IEA). (2011). Joint Public-Private Approaches for Energy Efficiency finance: Policies to scale-up private sector investment. Policy. France. Retrieved from www.iea.org/efficiency

International Renewable Energy Agency. (2012). Evaluating policies in support of the deployment of renewable power. International Renewable Energy Agency Policy Brief, 19. Retrieved from https://www.irena.org/DocumentDownloads/Publications/Evaluating_poli cies_in_support_of_the_deployment_of_renewable_power.pdf

IRENA. (2017). Renewable Energy and Jobs: Annual Review, 16.

Joelsson, J. M. (2011). On Swedish bioenergy strategies to reduce CO2 emissions and oil use. $\mathrm{PhD}$ Thesis.

Jue, E., Johnson, B., \& Vanamali, A. (2012). Case study: Thailand's Energy Conservation (ENCON) fund. How Financial Mechanisms Catalyzed Energy Efficiency and Renewable Energy Investments. Bangkok.

Keyuraphan, S., Thanarak, P., Ketjoy, N., \& Rakwichian, W. (2012). Subsidy schemes of renewable energy policy for electricity generation in Thailand. Procedia Engineering, 32, 440-448. https://doi.org/10.1016/j.proeng.2012.01.1291

Konkel, R. S. (2013). Renewable energy and sustainable communities: Alaska's wind generator experience. International Journal of Circumpolar Health, 72(1), 1-8. https://doi.org/10.3402/ijch.v72i0.21520

Lucas, H., Fifita, S., Talab, I., Marschel, C., \& Cabeza, L. F. (2017). Critical challenges and capacity building needs for renewable energy deployment in Pacific Small Island Developing States (Pacific SIDS). Renewable Energy, 107, 42-52. https://doi.org/10.1016/j.renene.20 17.01.029

Lüthi, S. (2011). Effective Renewable Energy Policy - Empirical Insights from Choice Experiments with Project Developers (Unpublish PhD Thesis). University of St. Gallen.

Luthra, S., Kumar, S., Garg, D., \& Haleem, A. (2015). Barriers to renewable/sustainable energy technologies adoption: Indian perspective. Renewable and Sustainable Energy Reviews, 41, 762-776. https://doi.org/10.1016/j.rser.2014.08.077

Martin, N., \& Rice, J. (2015). Improving Australia's renewable energy project policy and planning: A multiple stakeholder analysis. Energy Policy, 84, 128-141. https://doi.org/10.1016/j.enpol.2015.04.034

Menanteau, P., Finon, D., \& Lamy, M. L. (2003). Prices versus quantities: Choosing policies for promoting the development of renewable energy. Energy Policy, 31(8), 799-812. https://doi.org/10.1016/S0301-4215(02)00133-7 


\section{Macrothink Institute ${ }^{\mathrm{TM}}$}

Meyer, N. I. (2007). Learning from wind energy policy in the EU: Lessons from Denmark, Sweden, and Spain. European Environment, 17(5), 347-362. https://doi.org/10.1002/eet.463

Musango, J. K., \& Brent, A. C. (2010). Energy for Sustainable Development A conceptual framework for energy technology sustainability assessment. Energy for Sustainable Development, 15(1), 84-91.

Nasirov, S., Silva, C., \& Agostini, C. A. (2015). Investors' perspectives on barriers to the deployment of renewable energy sources in Chile. Energies, 8(5), 3794-3814. https://doi.org/10.3390/en8053794

Nilsson, M., Lucas, P., \& Yoshida, T. (2013). Towards an Integrated Framework for SDGs: Ultimate and Enabling Goals for the Case of Energy. Sustainability, 5(10), 4124-4151. https://doi.org/10.3390/su5104124

Noim Uddin, S., \& Taplin, R. (2009). Trends in renewable energy strategy development and the role of CDM in Bangladesh. Energy Policy, 37(1), 281-289. https://doi.org/10.10 16/j.enpol.2008.08.026

Nsasira, R., Basheka, B. C., \& Oluka, P. N. (2013). Public Private Partnerships (PPPs) and Enhanced Service Delivery in Uganda: Implications from the Energy Sector. International Journal of Business Administration, 4(3), 48-60. https://doi.org/10.5430/ijba.v4n3p48

Okundamiya, M. S., Emagbetere, J. O., \& Ogujor, E. A. (2014). Assessment of renewable energy technology and a case of sustainable energy in mobile telecommunication sector. The Scientific World Journal. https://doi.org/10.1155/2014/947281

Pongsiri, N. (2003). Public-Private Partnerships in Thailand: A Case Study of the Electric Utility Industry. Public Policy and Administration, 18(3), 69-90. https://doi.org/10.1177/09 5207670301800306

Pongsiri, N. (2004). Partnerships in oil and gas production-sharing contracts. International Journal of Public Sector Management, 17, 431-442. https://doi.org/10.1108/095135504105 46606

Sawin, J. L., Seyboth, K., \& Sverrisson, F. (2016). Renewables 2016: Global Status Report. Ren21.

Sheikh, N. J., Kocaoglu, D. F., \& Lutzenhiser, L. (2016). Social and political impacts of renewable energy: Literature review. Technological Forecasting and Social Change, 108, 102-110. https://doi.org/10.1016/j.techfore.2016.04.022

Thanh Nguyen, N., Ha-Duong, M., Tran, T. C., Shrestha, R. M., \& Nadaud, F. (2010). Barriers to the adoption of renewable and energy-efficient technologies in the Vietnamese power sector. GMSARN International Journal, 4(2), 89-104.

The Board of Investment of Thailand. (2015). Thailand Alternative Energy. Bangkok, Thailand. Retrieved from http://www.boi.go.th/upload/content/BOI-brochure2015-alt energy -20151222_30264.pdf 


\section{Macrothink}

International Journal of Global Sustainability

ISSN 1937-7924 2019, Vol. 3, No. 1

Timmons, D., Harris, J. M., \& Roach, B. (2009). The Economics of Renewable Energy. Renewable Energy, No. 15081, 1341-1356.

Tongsopit, S. (2016). Thailand's Renewable Development Status and Recommendations. In Workshop on Electricty Security in Thailand: A Joint Workshop by IEA, MOE, and ERI. Bangkok, Thailand.

Tongsopit, S., \& Greacen, C. (2013). An assessment of Thailand's feed-in tariff program. Renewable Energy, 60, 439-445. https://doi.org/10.1016/j.renene.2013.05.036

Urban, F. (2009). Sustainable energy for developing countries: modelling transitions to renewable and clean energy in rapidly developing countries. Sustainable energy for developing countries: modelling transitions to renewable and clean energy in rapidly developing countries.

Varas, P., Tironi, M., Rudnick, H., \& Rodriguez, N. (2013). Latin America goes electric: The growing social challenges of hydroelectric development. IEEE Power and Energy Magazine, 11(3), 66-75. https://doi.org/10.1109/MPE.2013.2245586

Vilanova, M. R. N., Magalh\&atilde;es Filho, P., \& Balestieri, J. A. P. (2015). Performance measurement and indicators for water supply management: Review and international cases. Renewable and Sustainable Energy Reviews, 43, 1-12. https://doi.org/10.1016/j.rser.201 4.11 .043

Vine, E., Hamrin, J., Eyre, N., Crossley, D., Maloney, M., \& Watt, G. (2003). Public policy analysis of energy efficiency and load management in changing electricity businesses. Energy Policy, 31(5), 405-430.

Wattana, S. (2014). Bioenergy development in Thailand: Challenges and strategies. Energy Procedia, 52, 506-515. https://doi.org/10.1016/j.egypro.2014.07.104

Wiser, R., \& Pickle, S. (1997). Financing Investments in Renewable Energy: The Role of Policy Design and Restructuring. Contract, (March).

\section{Appendix}

Appendix 1. Survey Questions

Table 1. Sustainable RE policy development scale

\begin{tabular}{lllll}
\hline Description & Disagree & $\begin{array}{l}\text { Neither } \\
\text { agree } \\
\text { disagree }\end{array}$ & Agree & Total \\
\hline $\begin{array}{l}\text { To what extent does political } \\
\text { stability impacts on renewable } \\
\text { energy deployment in Thailand? }\end{array}$ & 35.7 & 53.3 & 100.00 \\
\hline
\end{tabular}


Neither

Agree 2019, Vol. 3, No. 1

Government policy on renewable

25.3

29.5

45.2

100.00

energy development is stable

Government support renewable

13.9

29.1

57.0

100.00

energy policy development

through tax incentives and

subsidies

The government has provided

30.3

46.1

23.6

100.00

efficient policy measures on renewable energy technologies in the past

The renewable energy sector has

relatively stable policy instruments for sustainable renewable supply

The frequent policy changes and discontinuation of policies undermine the growth of the renewable energy sector in Thailand

Political priorities are directed to ensuring that the effectiveness of policy instruments in the renewable energy sector

Government commitment to 27.7

funding and financing renewable energy technology is cost-effective

The government has provided 27.8 intensive capital sources for SMEs that are interested in developing renewable energy technologies at cost-effective prices

There are measures put in place 16.3 
Neither

Agree 2019, Vol. 3, No. 1

agree nor

disagree

power producers in the sector

Government policy on renewable

15.1

29.7

55.2

100.00

energy accounts for energy price controls

Government policy instrument on

19.4

28.5

52.1

100.00

feed-in-tariffs is cost-effective and supports renewable energy deployment by both big and small energy producers

The current policy instrument on

renewable energy sources can achieve the country's target of $40 \%$ of renewable energy supply by 2036

How would you rate policy stability on renewable energy in the country?

Sustainable

RE Policy 14.4

40.4

45.2

100.00

Development: Overall

Note: $\dot{X}=5.31, \mathrm{SD}=1.40, \mathrm{Min}=2, \mathrm{Max}=10, \mathrm{~N}=165$

Table 2. Government subsidies scale

\begin{tabular}{llllll}
\hline Description & Response & Frequency & Percentage (\%) & Total & N \\
\hline $\begin{array}{l}\text { Does the state } \\
\text { government }\end{array}$ & Yes & 52 & 31.3 & & \\
provide investors & No & 114 & 68.7 & 100.00 & 166 \\
$\begin{array}{l}\text { with subsidies or } \\
\text { financial incentives } \\
\text { to investors? }\end{array}$ & & & & \\
\hline
\end{tabular}

Note: $\dot{\mathrm{X}}=1.69, \mathrm{SD}=0.47, \mathrm{Min}=1, \mathrm{Max}=2, \mathrm{~N}=166$ 


\section{Macrothink}

Table 3. Government R\&D framework scale

\begin{tabular}{lllll}
\hline Description & Disagree & $\begin{array}{l}\text { Neither agree } \\
\text { nor disagree }\end{array}$ & Agree & Total \\
\hline $\begin{array}{l}\text { The government has allocated funding for } \\
\text { R\&D for future renewable energy development }\end{array}$ & 29.1 & 56.4 & 100.00 \\
$\begin{array}{l}\text { The government has provided laboratories and } \\
\text { learning centers for research on renewable } \\
\text { energy technology development }\end{array}$ & 27.9 & 43.0 & 100.00 \\
$\begin{array}{l}\text { Government support technology transfer in the } \\
\text { renewable energy sector through research and } \\
\text { innovation }\end{array}$ & & & & \\
$\begin{array}{l}\text { There is high public support and confidence of } \\
\text { government policy measures on renewable } \\
\text { energy technology in the country }\end{array}$ & & & & \\
\begin{tabular}{l} 
Governement R\&D: Overall \\
\hline
\end{tabular}
\end{tabular}

Note: $\dot{X}=6.01, \mathrm{SD}=2.06, \mathrm{Min}=0, \mathrm{Max}=10, \mathrm{~N}=165$

Table 4. Regulations/administration procedures scale

\begin{tabular}{|c|c|c|c|c|}
\hline Description & Disagree & $\begin{array}{l}\text { Neither agree } \\
\text { nor disagree }\end{array}$ & Agree & Total \\
\hline $\begin{array}{l}\text { Compared to other ministries in } \\
\text { the ministry or ministries in } \\
\text { government responsible for } \\
\text { energy is/ are effective in issuing } \\
\text { out operating permits to power } \\
\text { procedures. }\end{array}$ & 64.2 & 24.8 & 23.0 & 100.00 \\
\hline $\begin{array}{l}\text { The regulations on renewable } \\
\text { energy are easy to understand and } \\
\text { applied }\end{array}$ & 24.8 & 43.0 & 32.1 & 100.00 \\
\hline $\begin{array}{l}\text { It is easy to secure an operating } \\
\text { permit or license to produce } \\
\text { renewable energy in the country }\end{array}$ & 21.8 & 39.4 & 38.9 & \\
\hline $\begin{array}{l}\text { The agencies responsible for } \\
\text { renewable energy sector ensures } \\
\text { that power producers follow } \\
\text { environmental and local laws } \\
\text { where plants are located }\end{array}$ & 12.1 & 28.3 & 59.6 & 100.00 \\
\hline The laws and regulations on & 11.6 & 27.4 & 61.0 & 100.00 \\
\hline
\end{tabular}


renewable energy deployment are monitored to ensure compliance by power producers

The regulatory and administrative 25.6 34.8 procedures are devoid of bureaucratic bottlenecks

The regulatory agencies ensure compliance with environmental impact assessment before permits are issued to renewable energy power producers

Regulatory/Administration

Procedures: Overall

$\begin{array}{llll}14.4 & 45.0 & 40.6 & 100.00\end{array}$

Note: $\dot{X}=5.73, \mathrm{SD}=1.65, \operatorname{Min}=0, \operatorname{Max}=10, \mathrm{~N}=165$

Table 5. Stakeholder involvement scale

\begin{tabular}{|c|c|c|c|c|}
\hline Description & Disagree & $\begin{array}{l}\text { Neither agree } \\
\text { or disagree }\end{array}$ & Agree & Total \\
\hline $\begin{array}{l}\text { Government policy frameworks } \\
\text { ensure adequate consultation } \\
\text { with communities where } \\
\text { renewable energy plants and } \\
\text { technology are located }\end{array}$ & 21.8 & 39.4 & 38.8 & 100.00 \\
\hline $\begin{array}{l}\text { How would you rate the } \\
\text { ministry or ministries with } \\
\text { responsibility for renewable } \\
\text { energy compared to other } \\
\text { agencies and businesses in the } \\
\text { energy sector }\end{array}$ & 19.4 & 54.5 & 26.1 & 100.00 \\
\hline $\begin{array}{l}\text { How would you compare the } \\
\text { Thai ministry or ministries } \\
\text { responsible for Renewable } \\
\text { energy to others in the ASEAN } \\
\text { region }\end{array}$ & 18.2 & 49.7 & 32.1 & 100.00 \\
\hline $\begin{array}{l}\text { The regulatory agencies share } \\
\text { information on its activities }\end{array}$ & 13.4 & 45.1 & 41.5 & 100.00 \\
\hline
\end{tabular}


Disagree

Neither agree Agree

Total or disagree

regularly with other

stakeholders in the sector

The government is willing to

change policy direction in the light of suggestions made by other energy stakeholders

The policy and regulatory agencies frequently
18.3
42.1
39.6
100.00

acknowledge persons in the community who have made significant contributions to renewable energy development

The regulatory agencies have

considerable control over the operations of renewable energy power producers

The regulatory agencies are

often forced to change policy direction because of the demands of the key stakeholder in the renewable energy sector

Stakeholder Involvement:

Overall

Note: $\dot{X}=5.73, \mathrm{SD}=1.65, \operatorname{Min}=0, \operatorname{Max}=10, \mathrm{~N}=165$

\section{Copyright Disclaimer}

Copyright for this article is retained by the author(s), with first publication rights granted to the journal.

This is an open-access article distributed under the terms and conditions of the Creative Commons Attribution license (http://creativecommons.org/licenses/by/3.0/). 